\title{
POUL VAD
}

\author{
Medea
}

Et år efter krigens afslutning rejste jeg til København og slog mig ned der for bestandig. Uden andre forudsætninger end en studentereksamen under middel blev jeg snart medarbejder ved et utraditionelt leksikon og på den måde opretholdt jeg tilværelsen to-tre år mens jeg skrev digte, ingen forlægger af gode grunde ville påtage sig at udgive. Som en bleg, hulkindet poet med hovedet fuldt af min egen 'sangen om mig selv', udfyldte jeg en ansvarsfuld post på leksikonredaktionen, hvor jeg blandt meget andet skrev små artikler om danske købstæder, jeg aldrig havde besøgt. Jeg skrev af efter pålidelige værker og tilføjede de nyeste oplysninger om indbyggertallet hentet i Statistisk Årbog.

Redaktionen var ikke en almindelig borgerlig arbejdsplads med almindelige borgerlige arbejdstider. Der var lys på redaktionskontorerne hver aften; og tit og ofte arbejdede vi også om søndagen. Vi levede og åndede for vores leksikon, chefredaktøren, redaktionssekretæren og jeg samt et par mere løst tilknyttede redaktionelle medarbejdere. Bunken af små sedler i A-s format, hvorpå jeg slrev artiklerne om danske købstæder, hobede sig op på mit arbejdsbord. Efterhånden blev de så anbragt i kartotekskasserne i det alfabetiske system, som også rummede alle de andre artikler på fra to til cirka ti linjer. Det var min opgave at holde orden i systemet når de forskellige bidragydere kom med deres stabler af små artikler, som de fik en ussel liniebetaling for. Det var som antallet af artikler formerede sig eksponentielt, min hjerne knagede under ansvaret og under denne frygtelige belejring.

Når jeg kom hjem, undertiden sent oni aftenen, åbnede jeg den tunge konvolut med den sidste returnerede digtsamling, som i dagens løb var dumpet ind gennem brevsprækken i lejligheden hos den dame, hvor jeg havde lejet et værelse. Men den følgende søndag holdt jeg fri og skrev $i$ inspirationens rus nogle nye digte. Jeg lod mig ikke slå ud.

Jeg begyndte at studere, men det havde jeg ikke forstand på. Jeg blev alligevel ved, ligesom i mangel af bedre og fordi jeg ikke kunne finde på noget andet, der måske pegede fremad.

Havde jeg ingen venner? Jo, min ven Bjørn boede kun et par gader fra redaktionen. Han havde et kvistværelse med udsigt til stjernehimlen og det gyldne kors på toppen af domkirken. Når han ikke spillede kort studerede han medicin. Sammen fablede vi om at vi vort liv til videnskaben. Det var en ren komedie vi spillede for og med binanden for at gøre vores usle, temmelig fattige og først og fremmest udsigtsløse liv udholdeligt. Alligevel var jeg ensom - det var han naturligvis også -, hvordan skulle jeg ellers kunne være den digter, jeg $\mathrm{i}$ al hernmelighed inderst inde var? 
På den tid hærgedes Danmark af en fransk bacille, der hed eksistentialismen. Jeg læste Frihedens veje af Sartre og gik alene i teatret og så hans Døde uden grave og Lukkede døre. Det foregik i teatrene ude på Frederiksberg Allé og da jeg boede på Amager og København stadig var som et kontinent med mægtige, uudforskede landområder for mig, var teaterbesøgene samtidig en slags opdagelsesrejser og sonderinger af en fremmed virkelighed, der fyldte mig med forundring.

Hver dag $\mathrm{i}$ disse måneder og år færdedes jeg i Holmbladsgade - for jeg boede $\mathrm{i}$ en sidegade til den som er for uværdig til at nævnes -, som om jeg var blevet forvist til en katastrofe, der havde antaget rumlig form og udstrækning. Det var en gade som var blottet for selv det mindste spor af personlighed; og netop deri bestod katastrofen. (Var, siger jeg udtrykkelig, for siden jeg forlod den har jeg altid undgået den, som man instinktivt undgår mennesker, der fảr en til at føle sig dårlig tilpas og som kun vækker ubehagelige minder, skønt man ikke kan sige hvorfor.) Den virkede anonym, stereotyp og uinteressant med sine fantasiforladte etageejendomme og fabrikker og måske også fordi den så så endeløs ud og ikke rigtig førte nogen steder hen - den gik vistnok nærmest i opløsning til sidst, det forestillede jeg mig i hvert fald; men jeg følte mig aldrig fristet til at undersøge det nærmere. Den ejede ikke en gnist af den proletariske stolthed, der knyttede sig til gaderne på Vesterbro og Nørrebro; og den havde heller ikke noget af Amagerbrogades farverige travlhed: når man netop fra Amagerbrogade drejede ind i Holmbladsgade var festen forbi, en livløshed hvis konkrete årsag var ubestemmelig - bemægtigede sig alt; og passagererne $i$ linje fem fik et fjendtligt udtryk $i$ øjnene, ikke rettet mod medpassagererne, som de knap nok ænsede, men mod - ja, mod hvad? det var netop gåden. Jeg lærte mere om livets alvor af Holmbladsgade end af Sartres romaner og skuespil; for denne franske hjernes udspekulerede iscenesættelse af menneskelig fortvivlelse, fornedrelse og lede, havde så at sige ingen vægtfylde når man kom fra Holmbladsgade, hvor ophidsende (også på mig) virkningen end var i øjeblikket. Holmbladsgade, det var en inkarnation af eksistensvilkårenes fundamentale inerti som ikke var til at komme uden om, som ikke var sæsonbestemt og som ikke lod sig rokke af en fransk filosofs spektakulære udlægning af en dybsindig idé, han havde lånt i Tyskland, men som oprindelig var udklækket af en eksisterende tænker med dansk dåbsattest.

Hvis de teatre hvor Sartres stykker blev spillet havde ligget i kvarteret ved Holmbladsgade, ville det have forandret stykkerne i bund og grund. En umulig tanke! Jeg måtte foretage rejsen ud til Frederiksberg Allé - for som en rejse følte jeg det - og lære denne fremmede verdensdel at kende, der syntes at grænse op til eller snarere være en del af et kosmopolitisk netværk; for de samme stykker blev jo spillet for fulde huse på små teatre i Paris og London. Selve den brede allé med træernes lange rækker var så indbydende, venlig og ligefrem poetisk på en beskeden, upretentiøs måde, at den virkede utroværdig. Jeg, som var brændemærket i sjælen af Holmbladsgade, antog uden videre dens lethed for letfærdighed og følte mig forvirret. Ved teatertid var mørket faldet på, folk sværmede foran de oplyste indgange som om de blev skubbet frem og tilbage af mærkelige drifter, de ikke havde styr på, og endte med at lade sig suge ind i de store, lukkede æsker med de polstrede stolerækker for at lade sig piske vellystigt af Sartres berømte sortsyn. Skuespillerne smed deres hadske replikker $\mathrm{i}$ hovedet på hinanden som om de udvekslede almindelige 
høflighedsfraser. Jeg følte mig indviet $\mathrm{i}$ en omgangsform, der tilsyneladende repræsenterede et højere stade af den menneskelige udvikling eftersom publikum, og herunder jeg selv, betalte dyre penge for at stifte bekendtskab med den. Replikkerne sved som øretæver og staklerne på scenen fejrede triumfer i den særlige form for nederdrægtighed, der var forfatterens speciale. Skønt de i deres roller så ud og gebærdede sig som ganske almindelige mennesker, som om de lige så godt kunne have været en del af publikum, var de i virkeligheden de modstandsløse ofre for en frygtindgydende metafysik. Når fælden smækkede $\mathrm{i}$ - det gjorde den altid - sprællede de længe uden at kunne røre sig ud af flækken samtidig med at de med mønstergyldig retorisk præcision formulerede deres gribende impotens. Tæppefald, bifald, fremkaldelser. Jeg klappede ihærdigt, og jo mere jeg klappede, jo mere overbevist følte jeg mig om at have oplevet noget storslået. Ude i Frederiksberg Allé spredtes publikum for alle vinde. Der var en ivrig snakken som snart fortonede sig. Stemmerne var oprømte og forskræmte, betroede sig til hinanden, diskuterede 'meningen med stykket' og skuespillernes præstationer. Snart var jeg alene. En enorm tomhed fyldte mig som en sødme. Vejen hjem til Amager føltes lang og da jeg sad i linje fem var alléen, teatret, skuespillerne og skuespillet allerede $\mathrm{i}$ færd med at fortone sig som noget, der ikke egentlig vedrørte mig og mit liv. Turen ud af Amager Boulevard var endeløs. Undervejs forekom det mig at sporvognen - som et bimmellegeme der trodser tyngdekraften og Newtons ligninger - havde revet sig løs fra byens egentlige og oprindelige organisme og nu stilede mod en del af det beboede univers, hvor det menneskelige krible-krable liv fulgte sine egne monotone forskrifter. Endelig drejede sporvognen ind i Holmbladsgade, vognstyreren ringede med klokken som om det var en festlig begivenhed, men blev modsagt af hjulene, der hvinede i skinnerne. Et par stoppesteder inde i gaden kunne jeg så stige af, nu helt og holdent opslugt af den væren-sig-selv-nok, der lå i luften og fik det eksistentialistiske teater til at virke som et eksotisk frikvarter. Da jeg lukkede mig ind på mit værelse i sidegaden havde jeg endnu en times tid at slå ihjel inden jeg lagde mig til at sove. Jeg skrev et brev om den oplevelse, jeg havde haft, fuldt af glødende fraser der meldte sig ubesværet, som om jeg slet ikke havde set noget teaterstykke, men fantaserede mig til det hele. Der var stillet et klædeskab foran døren ind til det andet værelse i den toværelses lejlighed, jeg delte med værtinden. Jeg kunne høre på stilheden at hun allerede sov.

I disse år strålede en sælsom stjerne på den danske teaterhimmel, ikke i zenith og ikke i nogen af de kendte konstellationer, men ligesom i sit eget utilgængelige og afsides dyb, hvor den funklede uforstyrret og ensomt: Inge Hvid-Møller. Jeg havde set hende $\mathrm{i}$ en film, derfor kendte jeg hende, jeg havde jo aldrig oplevet hende på scenen; og derfor stod hun for mig som et skyggeagtigt billede, en figur som den artificielle belysning knap nok hentede frem af det omgivende mørke, en slags mørkets engel, der fra sit skyggerige var trådt ind i den danske virkelighed, som hun ved sit blotte nærvær og ikke mindst i kraft af sin stemme forvandlede i bund og grund: en fløjlsblød, mørktfarvet stemme, hvis tonart var mol og hvis varme sensualitet ikke bare kærtegnede øret, men havde uhindret adgang til det indre, smøg sig om hjerteregionen, elektricerede hjernen og fik hele nervesystemet til at dirre. Hun optrådte sammen med Eyvind Johan-Svendsen i den sidste episode $\mathrm{i}$ filmen Otte ak- 
korder, og mens resten af filmen er slettet af hukommelsen, fortsætter Eyvind JohanSvendsen og Inge Hvid-Møller den natlige vanvidsdans, der afslutter filmen, men som for mig aldrig er hørt op. Engel, ja -; men her er det snarere to zombier der danser, for de er allerede fulde af død; og hans store korpus og hendes spinkle skikkelse er lige hjælpeløse. Og nu stod Inge Hvid-Møller pludselig der foran mig i kød og blod på scenen i Riddersalens lille teater, som Medea i Anouilhs skuespil. Anmeldelser og rygter var løbet $i$ forvejen: her foregik noget storslået, noget uhørt, en næsten skræmmende alkymi i fuld offentlighed, en frederiksbergsk teaterscene forvandlet til kultsted for en arkaisk mysteriereligion; som om der blev foretaget blodige ofringer på scenen. Aldrig havde rejsen fra Holmbladsgade været længere. Jeg vidste ikke om jeg kunne tro hverken anmeldelser eller rygter, for hvis jeg virkelig granskede min sjæl og stillede mig ansigt til ansigt med mig selv, vidste jeg godt at både anmeldelser og rygter kunne lyve: den virkelighed (altså teatervirkelighed!) de henviste til, holdt ikke hvad de lovede. Men de anmeldere kendte garanteret heller ikke den virkelige virkelighed, sådan som den tog sig ud når man kom fra Holmbladsgade. De lod sig narre af noget der lignede. Jeg fandt min plads og den lille sal var snart propfyldt - stykket havde allerede længe gået for fulde huse. Da tæppet gik op og jeg så og ikke mindst hørte Inge Hvid-Møller var jeg med det samme fuldstændig fortabt. Hendes ansigtstræk var en smule uregelmæssige på en måde, som er umulig at beskrive, med læber der ikke havde den klassiske, harmoniske form, man normalt forbinder med skønhed - de var fyldige, som om de svulmede lidt mere end tilladeligt, og dog finttegnede, uden blot det mindste anstrøg af vulgaritet; snarere som om de for altid var mærket af en eller anden smerte. Intet ved hendes ansigt virkede almindeligt; men hvis man ville sige at det virkede påfaldende, var det dog på en diskret måde. Men det var først og fremmest de strålende mørke øjne og ansigtstrækkenes modne sødme, der gjorde hende så fortryllende. Og som sagt: da hun åbnede munden fyldte hun teatersalen med sin stemmes musik, der havde samme besnærende virkning som et ubegribeligt orientalsk krydderi. Alene dette var i sig selv tilstrækkeligt til at løfte forestillingen højt over de eksistentialistiske melodramaer, jeg havde ladet mig forføre af trods en modvilje, jeg ikke selv forstod. Der var naturligvis også andre skuespillere på scenen end Inge Hvid-Møller, udmærkede skuespillere, men dem har jeg tilladt mig at glemme. Jeg tror de ville forstå mig og tilgive mig, men hvis det ikke skulle være tilfældet er jeg iøvrigt ligeglad.

Måske ville jeg $\mathrm{i}$ virkeligheden også have glemt Inge Hvid-Møller - erindringen om hende ville i det mindste være blegnet - hvis ikke der var sket noget skræmmende. Jeg var uforberedt på hvilke kræfter der kunne bo $i$ sådan en kvindeskikkelse. Jeg havde ikke i tilstrækkelig grad heftet mig ved at hun var Medea; men hun skulle sørge for at jeg aldrig kom til at glemme det.

Ret beset er teatret en plat og vulgær foranstaltning, derpå beror dets styrke når det så endelig lykkes - det vil sige, når det hæver sig over denne foranstaltning og for øjnene af os forvandler den til sin modsætning. Blot den måde, hvorpå skuespillerne kommer marcherende ind på scenen (utroligt at man finder sig i det!), ind på scenens brædder, der må finde sig $\mathrm{i}$ at bære disse opstyltede personer, der altid og under alle omstændigheder er totalt utroværdige. Men at Medea, Jason og Kreon, 
iført forlorne kostumer, der lyste langt væk af teaterskrædderi, spadserede rundt på brædderne i scenens lille kukkasse så det rungede hult af deres trin, forhindrede ikke dramaet på liv og død i at løfte sig med tankens skønhed og ordene i at bore sig lige ind i hjertekulen på alle os, der åndeløst fulgte dem i det tætpakkede tilskuerrum. Medea var og forblev centrum i det, der foregik, og det lykkedes endog Inge HvidMøller at indblæse de enkle gevandter, der indhyllede hende, et magisk liv som gjorde dem tidløse og dermed forvandlede den grusomme heks til vores samtidige. Hun var $i$ det hele taget $i$ besiddelse at en sådan kraft og intelligens, at jo mere den snuhed og grusomhed, der var en del af hendes natur - og som til syvende og sidst var hendes eneste middel til selvforsvar - tog overhånd, jo stærkere og mere uafrystelig blev den skruestik, hun holdt os fast $\mathbf{i}$.

Jeg forestiller mig at det ville være løbet Anouilh selv - og sikkert også Euripides - koldt ned af ryggen hvis han havde oplevet den Medea, hans tekst her havde fostret. Ha! tekstens bogstav var som scenens brædder, som teaterskrædderens kostumer, som kukkassens begrænsning - på én gang forhindring og forudsætning, men under alle omstændigheder utilstrækkelig som forklaring på den psyko-fysiske alkymi, der fuldbyrdedes her for øjnene af os. For ligesom jorden åbner sig under vulkanudbrud og jordskælv og i ét nu kuldkaster den primitive, fysiske forestilling om fast grund under fødderne, som måske er en stærkere, mere fundamental ontologisk forudsætning for vores oplevelse af væren end dén bevidsthed, evolutionen har beriget os med, sådan kuldkastede Inge Hvid-Møller alle forestillinger om hvad en teaterscene er. Hun slog publikum med en sådan henrykkelse og rædsel, at de tilbageholdte åndedræt fængsledes i de kroppe, der anspændt pressedes tilbage mod stoleryggene. Hun kuldkastede også den forestilling om hvad en kvinde er, der er sanktioneret af samfundet og som flertallet - selv blandt kvinderne - helst klynger sig til.

Allerede librettoen, som jeg i denne sammenhæng fristes til at kalde Anouilhs dramatiske tekst, lagde op til en Medea, der med sine forbrydelser overskrider grænser, vi anser for ukrænkelige, og dermed forvandler sig selv til et uhyre. Det går op for Medea at hun har tabt spillet: Jason har svigtet hende, hun får ham aldrig tilbage hun som ofrede alt for hans skyld. Men de kender hende ikke: aner ikke hvad hun er i stand til og at hun mindst af alt sparer sig selv når det gælder om at udtænke den grusomst mulige hævn. I Inge Hvid-Møllers fremstilling blev rædslens højdepunkt ikke hævnplanernes iscenesættelse, men de øjeblikke, da en anden, frygtelig Medea gennembryder den person, hun hidtil har været, da denne anden person fødes med skrig så gennemtrængende, animalske og triumferende at publikum bestemt ville være styrtet $u d$ af teatret hvis ikke rampen havde været der som markeringen af en uoversluridelig grænse.

Tekstens ord som det ville være helt misvisende at kalde en replik, er ikke andet end sort tryksværte på hvidt papir: Jeg er Medea. På det tidspunkt, hvor udbruddet kommer, var Inge Hvid-Møller, alene på scenen, netop gået frem til rampen. Der stod hun nu, vendt mod salen; og jeg kunne mærke at alle de andre tilskuere var lige så skræmte fra vid og sans som jeg selv. Hendes ansigt var frygteligt, med vidt opspilede øjne, der lyste som af et ukontrolleret afsind, mens hun bredte armene vidt ud, som om hun var en kæmpemæssig fugl. Hendes bryst bølgede som om en 
vejrtrækning, der tilhørte en meget større og mere ekstatisk krop end hendes egen, gennemrystede den indefra; og da hun åbnede munden så det ud som om den lyd, der skulle komme ud af den, var for stor for det smukke, glødende hoved og ville efterlade det som en blodig, sønderrevet maske. Egentlig skreg hun ikke: Jeg er Medea! Skrig er halsens modifikation af en større, mere frygtelig lyd. Skrig er stemmebåndenes hysteriske kontrol med en lyd, der fødes i maven. Hun brølede sin trussel og triumf ud som om det var indvoldene selv, dampende og blodfyldte, der kom til orde; men hvad værre var: hun brølede artikuleret og med en beherskelse af intonationen, som om hjernen og indvoldene havde slået sig sammen; med det resultat at de tre ord jeg og er og Medea rungede i ørerne, som blev de ramt af tre trykbølger. Det ville være løbet mig koldt ned af ryggen hvis jeg havde kunnet mærke ryggen; men hvis jeg kunne mærke noget var det snarere en slags lammelse, der også var en henrykkelse. Den sødmefulde, modne kvinde havde født en rædselsvækkende furie, som om hun med sit skrig, sit brøl; sit råb, ublufærdigt havde vendt vrangen ud på sig selv.

Fortumlet som efter en lmock-out tog jeg hjem til Holmbladsgade. Hendes råb blev ved med at gjalde i mine ører og give genlyd i min hjerne. I stilheden i det lille værelse i sidegaden var Inge Hvid-Møller nærværende, og jeg tilbad hende fordi hun var noget andet; noget jeg på en mærkelig måde genkendte. Sikke en kvinde! Hun var så voldsom at hun kunne måle sig med Holmbladsgades virkelighed, men desuden mere eventyrlig. Ja, jeg tilbad hende, men uden at forstå mine egne følelser. Jeg gik ikke til min ven Bjørn og sagde: Jeg tilbeder Inge Hvid-Møller. For jeg vidste slet ikke at der var tale om tilbedelse, jeg var bare helt fyldt af hende som om jeg skulle sprænges. Tilbedelse - det var et ord som ville have forekommet mig alt for overspændt; men idag er jeg glad for at kunne sige det som det er. $\mathrm{Og}$ på den ene side brændte jeg på en måde efter at dele disse følelser med nogen, på den anden side ville jeg netop holde dem for mig selv. Jeg havde aldrig forestillet mig at jeg nogen sinde skulle fă min tilbedelse bekræftet eller godkendt af den eneste, der var i stand til det; men det fik jeg: jeg fik et svar på den; jeg fik et tegn.

Da var jeg for længst flyttet fra Holmbladsgade, som jeg ganske vist ikke glemte - aldrig glemte -, men hvor jeg ikke havde til hensigt at leve resten af mit liv. Der gik tre-fire år, militærnægterlejren i Gribskov var foruden rigtige militærnægtere af den slags der tror på at resten af menneskeheden holder op med at slås bare fordi de selv nægter at bære våben - befolket af Jehovas Vidner, kommunister, fantaster, kvækere og forvirrede idealister med kunstneriske tilbøjeligheder samt et antal individer, der umuligt kunne klassificeres - kort sagt en samling originaler, der trissede fredeligt rundt $i$ den store skov og af og til forsigtigt stak spaden ned $i$ en grøft, der trængte til at renses; eller hvad ledelsen nu ellers kunne finde på at sætte dem til. Det var en voldsom overgang fra Holmbladsgades dræbende almindelighed og evige forudsigelighed til baraklivets anarki nødtørftigt reguleret af morgenvælming, spisetider osv. Lugten af mænd, af mandskroppe og af mænds tøj, var den hele tiden påtrængende realitet, selv i søvne føltes den. Måske var den endda særlig påtrængende om natten, hvor disse unge mandskroppe hver især var sunket ned $\mathrm{i}$ deres egne, private floder af søvn, der førte dem gennem gud ved hvilke drømmelandskaber. Om morgenen, i sovesalens beklumrede luft, var hovedet endnu tungt 
af den kollektive hørm, men et par mundfulde frisk luft var nok til at feje hjernen ren. Heldigvis fandt jeg i lejren ligesindede, der også var mere eller mindre forpint af en åndelig hunger, der med forkærlighed blev stimuleret ved læsning af dystre forfattere som Faulkner og Dostojevskij. Dem kunne vi af gode grunde ikke invitere til at optræde ved et af de aftenarrangementer, der $\mathrm{i}$ vinterens løb skulle skabe lidt kulturel afveksling i det dødssyge barakliv. I stedet fik vi arrangeret foredrag af mere lokale litterære personligheder og publicister og forskellige oplæsninger af skuespillere som vi følte, ville være vores antimilitaristiske sag gunstigt stemt. Måske var det mig selv der foreslog Inge Hvid-Møller, men det er nu langt fra sikkert. I hvert fald blev det ikke mig, men Jørgen der skulle tage sig af sagen. Godt det samme. Jeg, der endnu havde sjælen fuld af Holmbladsgade, ville sandsynligvis have kludret sådan i det, af ren og skær forlegenhed, at arrangementet aldrig var blevet til noget eller var endt som en fiasko. Jørgen besad den kulturelle sikkerhed der skulle til, sådan som det også viste sig den vinteraften, Inge Hvid-Møller ankom.

Selve nattemørket gjorde hendes tilstedeværelse mere eventyrlig. Lejren lå midt $\mathrm{i}$ skoven, hun var stået af toget ved et trinbræt, hvor Jørgen havde hentet hende, de var fulgtes gennem den natmørke skov til de kom til lejren, en lille klynge barakker og huse med lys i vinduerne og et par lamper, der lige netop oplyste den vej, som her svingede ud af skoven og forsvandt ind $\mathrm{i}$ den igen; og hun havde tisset $\mathrm{i}$ den bygning med pissoir og en række WC-aflukker, vi havde til rådighed.

Som en lille, mørk, blid herskerinde stod hun foran os. Hun behøvede ikke at hæve stemmen, der kærtegnede ordene og fik dem til at lyde som de tilhørte et andet tungemål end det, vi selv benyttede. Hun løftede højre hånd og med en let bevægelse af pegefingeren tryllebandt hun hele den uhomogene forsamling af unge, ufærdige mænd vi var, som om vi godt kunne begynde helt forfra med at finde ud af hvad en hånd og en pegefinger for slet ikke at sige en kvinde i det hele taget var for noget. Vi slugte hende med øjnene, bange for at gå glip af blot den mindste nuance $\mathrm{i}$ hendes minespil, samtidig med at vi var lutter øre. Det var første gang nogen af os havde været blot i nærheden af en kvinde som hun. Det var nærmest utroværdigt at hun stod her, et par meter borte, og dog så selvfølgeligt. Hun forvandlede digtningens abstrakte udsagn, fængslet $\mathrm{i}$ ordene, til en slags livsånde der bølgede i rummet og næsten var til at tage og føle på. Stemmens molklang talte om hemmelige resonanser dybt inde $\mathrm{i}$ hendes krop. Vi klappede ubehersket mellem hvert nummer. Mens hun læste sad vi musestille som om vi var bange for at vore store, alt for klodsede kroppe blot ved en enkelt bevægelse skulle kunne krænke denne udsøgte skabning, der gjorde os pinligt forlegne. Den vanvittige Medea, jeg var blevet så betaget af, stiftede vi naturligvis ikke bekendtskab med - hende havde jeg for mig selv; og havde jeg fortalt om hende, ville ingen have troet mig. Hvordan skulle jeg kunne få mine kammerater til at se et uvejr, en troldkyndig, hævngerrig furie i den sødmefulde kvinde, der forkælede os med sin stemme, der var som en honning krydret med smagen af vilde blomster? Afnæægtigt følte jeg afstanden til hende vokse. I erindringen havde jeg besiddet hende gennem den tilbedelse, jeg gjorde hende til genstand for. Hun var et ikon jeg havde trykket til mit hjerte. Nu, hvor hun stod foran mig i kød og blod, var hun nærmere og derfor også mere overvældende end noget ikon, og først og fremmest mere virkelig; men også mere uop- 
nåelig. Jeg kunne ikke gøre større krav på hende - eller rettere på oplevelsen af hende - end nogen af de kammerater der omgav mig, hvilket jeg følte som en stor uretfærdighed og egentlig slet ikke kunne anerkende. Jeg kunne ikke dele hende med nogen. Jeg var $i$ virkeligheden alene med hende, skønt jeg var mig pinligt bevidst at jeg også var alene om at se sådan på det.

Inge Hvid-Møller - at hun var en person jeg skulle kunne tiltale eller blot omtale som Inge var aldrig faldet mig ind, verden var ikke skruet sådan sammen at det kunne lade sig tænke eller blot drømme - læste til sidst H.C. Andersens eventyr Dejlig, som slutter med ordet - dejlig. Da var det som om hun med en blid kvindehånd kneb os alle sammen i sjælen så det gjorde ondt.

Vi drak spandevis af sort kaffe og sænkede stemmerne til en mumlen som om vi af en eller anden grund skammede os over for denne kvinde, der nu drak kaffe og spiste sandkage sammen med os. Alle de frække fyre der til daglig kæftede op, støjede, bandede, brokkede sig og tog gas på hinanden var pludselig blevet artige som konfirmander talte de civiliseret, smilede belevent og udstød kun undtagelsesvis en slags kultiveret, overbærende latter som ikke havde meget til fælles med deres sædvanlige hånlige grin. Et sted ude til højre i mit synsfelt sad Inge. Jeg kunne godt dreje hovedet og kigge $\mathrm{i}$ hendes retning uden at det virkede alt for påfaldende, hvis jeg bare ikke overdrev. Det ville snarere have virket påfaldende hvis jeg slet ikke havde vist interesse for hende og skævet $\mathrm{i}$ hendes retning - det gjorde alle de andre jo. Det var Jørgen som sad der sammen med hende; og det var som det skulle være, det var jo ham der så at sige havde ansvaret for hende. Han sørgede for at hun følte sig godt tilpas.

Og sådan ville aftenen være endt for mig dersom jeg ikke endnu en gang havde drejet hovedet for at se $\mathrm{i}$ hendes retning. I samme øjeblik drejede hun selv ansigtet mod mig, vore blikke mødtes, et langt øjeblik så vi hinanden ind i øjnene og jeg følte den intime berøring, der kan være lige så stærk som nogen fysisk og som fik omgivelserne til at forsvinde som om de var en ligegyldig og irrelevant omstændighed. Til trods for den uoverskridelige afgrund, der skilte os, fyldte det blik vi udvekslede med hinanden mig med stolthed. Som i en uvilkårlig, dyb fortrolighed udvekslede vi intime hemmeligheder. Hun slog ikke blikket ned, men fastholdt tvært imod mit. Idet hun besvarede den tilbedelse, jeg ikke har kunnet eller villet skjule, skænkede hun mig en viden om mig selv, jeg ikke kunne have hentet andre steder. Jeg følte mig udmærket, jeg var blevet betroet en dyrebar viden og havde modtaget en anerkendelse dybt nede fra hendes køn, som jeg måtte holde for mig selv; og som indeholdt ligesom en vejledning jeg måske endnu slet ikke var $i$ stand til at forstå, men som uundgåeligt ville komme til at spille en rolle i mit liv. Spørgsmålet er om jeg overhovedet nogen sinde har forstået den. Spørgsmålet er om nogen mand nogen sinde ville kunne forstå den. Det er jeg ikke sikker på.

Efter denne aften fortsatte livet i lejren som det plejede, som om ingen ting var hændt. 